Children with microcephaly and non-Hodgkin's lymphoma (NHL)

\begin{tabular}{|c|c|c|c|c|c|c|c|c|}
\hline $\begin{array}{l}\text { Case } \\
\text { No }\end{array}$ & Sex & $\begin{array}{l}\text { Age at } \\
\text { diagnosis } \\
\text { (years) }\end{array}$ & $\begin{array}{l}\text { Type } \\
\text { of } \\
\text { NHL }\end{array}$ & $\begin{array}{l}\text { NHL } \\
\text { stage }\end{array}$ & Immunodeficiency & $\begin{array}{l}\text { Family } \\
\text { history }\end{array}$ & $\begin{array}{l}\text { Mental } \\
\text { development } \dagger\end{array}$ & $\begin{array}{l}\text { Outcome } \\
\text { (survival) }\end{array}$ \\
\hline 1 & $\mathrm{~F}$ & 8 & $\star$ & II & IgA decreased & * & Retarded & Dead (4 months) \\
\hline 2 & $\mathbf{M}$ & 3 & $\begin{array}{c}\text { Probably } \\
\text { B }\end{array}$ & III & & Negative & $\star$ & Dead (2 weeks) \\
\hline 3 & $\mathbf{M}$ & 15 & $\begin{array}{l}\text { Probably } \\
\text { T }\end{array}$ & III & $\begin{array}{l}\text { Frequent } \\
\text { respiratory } \\
\text { infections }\end{array}$ & $\begin{array}{l}\text { Positive for } \\
\quad \text { abnormalities }\end{array}$ & IQ 48 & $\begin{array}{l}\text { Dead, NED (15 } \\
\text { months), } \\
\text { pericarditis }\end{array}$ \\
\hline 4 & $\mathbf{M}$ & 7 & $\mathrm{~T}$ & III & $\star$ & Negative & IQ 61 & $\begin{array}{l}\text { Alive in I } \\
\text { remission (38 } \\
\text { months) }\end{array}$ \\
\hline 5 & $\mathbf{M}$ & 6 & B & III & $\begin{array}{l}\text { Decreased } \\
\text { reaction to } \\
\text { mitogen }\end{array}$ & $\begin{array}{l}\text { Sister with } \\
\quad \text { cerebral palsy }\end{array}$ & IQ 76 (TM) & $\begin{array}{l}\text { Alive in I } \\
\text { remission (35 } \\
\text { months) }\end{array}$ \\
\hline 6 & $\mathbf{M}$ & 10 & $\mathrm{~T}$ & IV & $\begin{array}{l}\text { IgA decreased, } \\
\text { low B cell, low } \\
\text { T cell }\end{array}$ & $\begin{array}{l}\text { Sister with } \\
\text { microcephaly }\end{array}$ & IQ 77 & $\begin{array}{l}\text { Alive in II } \\
\text { remission (28 } \\
\text { months) }\end{array}$ \\
\hline 7 & $\mathbf{M}$ & 13 & $\mathrm{~T}$ & IV & $\begin{array}{l}\text { IgG, IgA slightly } \\
\text { decreased }\end{array}$ & $\begin{array}{l}\text { Sister with } \\
\text { microcephaly }\end{array}$ & $\begin{array}{l}\text { IQ } 64 \text { (normal } \\
\text { school) }\end{array}$ & $\begin{array}{l}\text { Alive in I } \\
\text { remission (29 } \\
\text { months) }\end{array}$ \\
\hline 8 & $\mathrm{~F}$ & 3 & B & II & $\begin{array}{l}\text { IgA slightly } \\
\text { decreased }\end{array}$ & Negative & IQ 76 (TM) & $\begin{array}{l}\text { Alive in I } \\
\text { remission (18 } \\
\text { months) }\end{array}$ \\
\hline 9 & $\mathbf{M}$ & 9 & $\mathrm{~T}$ & II & $\begin{array}{l}\text { IgA decreased, } \\
\text { low B cell low } \\
\text { C4 }\end{array}$ & $\begin{array}{l}\text { Brother with } \\
\text { hydrocephalus } \\
\text { and foot } \\
\text { malformation }\end{array}$ & IQ 87 & $\begin{array}{l}\text { Alive in I } \\
\text { remission (4 } \\
\text { months) }\end{array}$ \\
\hline
\end{tabular}

* Lack of information. IQ measured on Wechsler scale or Termann-Merill (TM) scale.

$\ddagger$ Child from hospital for mentally disabled; lack of more precise information. NED=no evidence of disease.

The data of our nine patients are shown in the table. Familial microcephaly was seen in two patients. In three families other congenital malformations were found, and immunodeficiency was confirmed in six patients.

The outcome of treatment was not affected by the presence of microcephaly, ${ }^{6}$ despite treatment modifications to reduce toxicity (including omission of alkylating agents and/or irradiation of the central nervous system). Unfortunately, we were unable to perform complete immunological and cytogenetical examinations in our patients. However, there are reasons to believe that most of our cases were truly children with Seemanova's syndrome. It will be necessary to study more children to help explain the relation between congenital malformations, immunodeficiency, and malignancy.

A DLUZNIEWSKA D TREDOWSKA-SKOCZEN J ARMATA Department of Pediatric Hematology, Department of Pediatric Hematology,
Polish American Institute of Pediatrics, Collegium Medicum, fagiellonian University, 265 Wielicka Str, 30-663 Cracow, Poland

1 Seemanova E, Passarge E, Beneskowa D, et al. Familial microcephaly with normal intelligence, immunodeficiency, and risk for lymphoreticular malignancies: a new autosomal recessive disorder. Am f Med Genet 1985; 20: 639-48.

2 Teebi AS, Al-Alavadi SA, White AG. Autosomal recessive nonsyndromal microcephaly with normal intelligence. Am $\mathcal{F}$ Med Genet 1987; 26: 355-9.

3 Maraschio P, Peretti D, Lambiase S, et al. A new chromosomal instability disorder. Clin Genet 1986; 30: 353-65.

4 Filipovich RD, Mathur A, Kamet D, et al. Primary immunodeficiencies: genetic risk factors for lymphoma. Cancer Res 1992; 52 (19 suppl): 5465-7.

5 Taalman RD, Mustinx TW, Weemaes CM, et al. Further delineation of the Nijmegen breakage syndrome. Am f Med Genet 1989; 32: 425-31.

6 Dluzniewska A, Depowska T, Skoczeń S. Influence of adherence to protocol on the treatment results on example of NHL patients treated at single institution from 1987 till 92 . Proceedings of the Fifth International Congress on Malignant Lymphomas. Lugano, Switzerland, 6-9 June 1993.

\section{Ocular relapse in acute lymphoblastic} leukaemia

EDITOR,-Ocular relapse associated with acute lymphoblastic leukaemia (ALL) is rarely seen nowadays as a result of improved treatment of childhood leukaemia. A 12 year old boy with ALL was treated in accordance with the recent UKALL protocol which did not include cranial irradiation. He developed leukaemic infiltration of his left eye while in remission and on maintenance chemotherapy, seven months after the original diagnosis. Lumbar puncture revealed central nervous system (CNS) relapse and he underwent local irradiation to the left orbit with a maximum dose of $800 \mathrm{cGy}$ and subsequently reinduction chemotherapy and craniospinal irradiation. After initial partial resolution of signs, infiltrates persisted and 10 weeks later he underwent further craniospinal irradiation with $2400 \mathrm{cGy}$ applied to the right and left cranium in 15 fractions with $6 \mathrm{MV} x$ rays, resulting in a gradual improvement over a three month period and he remained in remission.

By six months only residual pigmentary changes were observed in the fundus and maintenance treatment was stopped due to neutropenia with the CNS remaining clear of blast cells. However, two weeks later, he developed further ocular recurrence which temporarily resolved on treatment, and subsequently further ocular and CNS relapse, and died 11 months after his original ocular presentation.

Ocular involvement in leukaemia is most commonly a consequence of associated haematological abnormalities and usually occurs when the patient is in relapse. Anaemia may precipitate a leukaemic retinopathy and hyperviscosity may give rise to microaneurysms, capillary closure, and retinal neovascularisation. Less frequently direct invasion of leukaemic cells may lead to ocular infiltration which carries a poor prognosis and is associated with CNS relapse. ${ }^{1}$ A recent study revealed $96 \%$ of children with ALL died within 28 months of onset of ocular signs. Of those patients with ocular manifestations in ALL, $82 \%$ had CNS leukaemia. ${ }^{2}$ It has been shown that intrathecal methotrexate does not reach the eye, and its effect on tumour cells in the optic nerve is demonstrable only as far as the termination of the subdural space posterior to the globe. ${ }^{3}$

A multicentre study of leukaemic ophthalmopathy suggests that those leukaemic patients with ocular involvement, in first complete remission, may be cured with chemotherapy and high dose radiotherapy to the affected eye, ${ }^{4}$ and it is still possible to achieve remission after a second ocular relapse. If the eye is the sole sanctuary site, then enucleation may be indicated. Lo Curto and associates presented a case of isolated ocular relapse in which enucleation was undertaken after a third ocular relapse. The eye had previously been treated with chemotherapy and radiotherapy with a dose of $390 \mathrm{cGy}$ at first relapse and $20 \mathrm{~Gy}$ at the second. The patient remained well 11 years after enucleation. It has been proposed that a dose of $20 \mathrm{~Gy}$ may be ineffective against ocular leukaemia, and that higher doses of over $30 \mathrm{~Gy}$ may be necessary to eradicate ocular leukaemic cells. 4

Although ocular sanctuary is a well known but very rare form of relapse, its occurrence is associated with an extremely poor prognosis and high dose radiotherapy should be urgently instituted. As routine cranial irradiation is no longer mandatory for standard risk cases, it is important that such cases presenting with ocular relapse should be thoroughly assessed to ensure adequate evaluation of current treatment protocols.

A M MCELVANNEY
A E A RIDGWAY
Manchester Royal Eye Hospital,
Oxford Road,

Manchester M13 9WH

H R GATTAMANENI

Christie Hospital and Holt Radium Institute, Wilmslow Road,

Manchester M20 9BX R F STEVENS

Royal Manchester Children's Hospital, Hospital Road

Manchester M27 $1 \mathrm{HA}$

1 Rosenthal AR. Ocular manifestations of leukemia. A review. Ophthalmology 1983; 90: 899-905. Ohkoshi K, Tsiaras WG. Prognostic importance of ophthalmic manifestations in childhood leukaemia, $\mathrm{Br} 7$ Ophthalmol 1992; 76: 651-5. 3 Ellis W, Little HL Leukemic infiltration of the optic nerve head. Am f Ophthalmol 1973; 75: 867-71.

4 Lo Curto M, D'Angelo P, Lumia F, et al. Leukemic ophthalmopathy: a report of 21 pediatric cases. Med Pediatr Oncol 1994; 23: 8-13.

Guidelines for the establishment and operation of human milk banks in the

EDITOR,-Interest in milk banking (the collection, storage, and processing of donor mothers' breast milk), has lately reawakened. The last document to give guidance in this area was published by DHSS in $1981,{ }^{1}$ but there have been many changes since then, including the emergence of HIV and other viral infections. A milk banking symposium in March 1993 marking the closure of Sorrento Maternity Hospital, Birmingham (which had been in the forefront of milk banking in the $\mathrm{UK}^{2}$ ) highlighted the need to update $\mathrm{UK}$ guidelines. An ad hoc working party was therefore established and new guidelines drawn up similar to those published by the Human Milk Banking Association of North America. ${ }^{3}$

The selection of donor mothers was considered very carefully and the guidelines 
emphasise the need to screen for HIV, syphilis, HTLV I and II, and hepatitis B and C. The published guidelines include a sample information sheet about screening for infectious diseases and sample instructions for the expression of milk and the personal hygiene of donors. Detailed guidance is given on all milk banking procedures including microbiological screening and pasteurisation. A minimum exposure of $57^{\circ} \mathrm{C}$ for 30 minutes or a maximum of $63^{\circ} \mathrm{C}$ for 30 minutes is recommended and the importance of rigorous quality control stressed. Common questions about temperature and length of storage are answered and recommendations made for the handling and thawing of frozen pasteurised breast milk. Standards for documentation are provided to permit tracing of a donor, if necessary.

Established milk banks and those in the process of being set up will find this document valuable. It draws together evidence from 41 papers. The working party feel that it would be helpful if there was uniformity of practice throughout the UK and these guidelines might promote this. They have been published by the British Paediatric Association and are available from the BPA office (5 St Andrews Place, Regent's Park, London NW1 4LB) at a cost of $£ 4$.

The working party consisted of S E Balmer (formerly Sorrento Maternity Hospital, Birmingham), D Baum (Royal Hospital for Sick Children, Bristol), C Fisher (John Radcliffe Hospital, Oxford), A Nicoll (Communicable Disease Surveillance Centre, London), B A Wharton (British Nutrition Foundation, London), A F Williams (St George's Hospital, London), and $M$ Woolridge (Royal Hospital for Sick Children, Bristol). We are grateful to Egnell Ameda for providing financial assistance, enabling a meeting of the group members.

1 Department of Health and Social Security. The collection and storage of human milk. London: HMSO, 1981. (Report on health and social subjects No 22.)

2 Balmer SE, Wharton BA. Human milk banking at Sorrento Maternity Hospital, Birmingham. Arch Dis Child 1992; 67: 556-9.

3 Arnold LDW, Tully MR, eds. Guidelines for the establishment and operation of a donor human milk bank. West Hartord CT: Human Milk Banking Association of North America, 1993.

SUSAN E BALMER 79 Links Drive,

West Midlands B91 2Df A F WILLIAMS
BPA Standing Committee on Nutrition, $B P A$, 5 St Andrew's Place, Regents Park, London NW1 $4 L B$

Efficacy and cost effectiveness of inhaled steroids in asthma in a developing country: an epilogue

EDITOR,-I am grateful to Drs Costello and Woodward for their commentary on my paper. ${ }^{1}$

My patients were carefully selected on the degree of disability. Few paediatricians would have access to very large numbers of severe asthmatics and those included represent severe asthmatics in general with regard to the degree of severity, incidence of atopy, family history, age at onset, etc. Similar patients are the ones who consume the greatest amount of time and resources of health care providers. The clinical benefits demonstrated in the paper, especially reduction in breakthrough wheezing and avoidance of repeated hospitalisations, would lead to significant savings on scarce resources, even in the public sector.

In the Sri Lankan non-fee levying public sector, till very recently, the management of these severe asthmatics revolved round the use of oral $\beta$ agonists, oral theophyllines, and intermittent systemic steroids. However, I am pleased to report that on the basis of the work presented, the Sri Lankan Ministry of Health has agreed in principle to provide inhaled steroids through the paediatricians of the national health service. Presently, at Lady Ridgeway Hospital, we are able to prescribe these drugs to needy children, completely free of charge. This has resulted in a marked reduction in admissions for acute severe asthma.

The costs calculated were those that were incurred by the patients, inclusive of costs of hospitalisation, travelling, consultations, drugs, etc for the first year on treatment. The cost per consultation was Rs 125.00 ( $f 1.55)$, inhaler Rs 500.00 ( $£ 6.60$ ), and hospitalisation approximately Rs 600.00 to 800.00 $(£ 8.00$ to 10.50 ) per day. Each inhaler was sufficient for more than a month on maintenance dosage. The remarkable reduction of the costs (to about $£ 6.00$ ) per patient was achieved by very significant reductions in breakthrough wheezing and hospitalisations.

B J C PERERA Lady Ridgeway Hospital for Sick Children, Colombo 8, Sri Lanka

1 Perera BJC. Efficacy and cost effectiveness of inhaled steroids in asthma in a developing country. Arch Dis Child 1995; 72: 312-6. 